\title{
RUANG AKTIVITAS MASYARAKAT PULOMAS
}

\author{
William Adiputra Dharmawan ${ }^{1)}$, Doddy Yuono ${ }^{2)}$ \\ 1) Program Studi S1 Arsitektur, Fakultas Teknik, Universitas Tarumanagara, adiputra.william@gmail.com \\ 2) Program Studi S1 Arsitektur, Fakultas Teknik, Universitas Tarumanagara, masdoddyyuono@gmail.com
}

\begin{abstract}
Abstrak
Masyarakat modern memiliki tuntutan kehidupan yang sibuk dan padat. Tidak terkecuali penduduk Jakarta. Yang strata sosio-ekonominya bertumbuh secara cepat menjadi kalangan menengah ke atas. Kalangan ini memiliki kebutuhan ruang dan pola penggunaan ruang yang berbeda. Mereka memilih untuk tinggal di perumahan, menghabiskan waktu di mall dibanding di tempat yang lokal, dan umumnya memiliki pekerjaan 9-5. Penggunaan mall sebagai tempat publik berpotensi menjadi masalah, ketika kehidupan publik yang bisa menjadi karakter suatu tempat di alihkan ke tempat yang anonim seperti mall. Kurangnya kehidupan publik mengikis sense of place dan social capital yang dimiliki sebuah tempat. Selain itu mall juga membutuhkan komitmen energi yang besar untuk mencapai mall, pengunjung yang tidak menjalin komunitas, ekslusifitas terhadap kalangan menengah kebawah, dlsb. Third place yang lokal di usulkan sebagai solusi, untuk menarik kembali kehidupan publik di perumahan. Sebuah tempat yang mempunyai skala lebih kecil, menjadikan pengunjungnya sesama manusia, personal, membentuk komunitas, lokal sehingga kita tidak perlu banyak energi untuk mengunjungi tempat itu, dan terbuka bagi semua, sebuah third place. Di proyek tugas akhir ini, dipilih site tepat di tengah perumahan, di Pulomas. Warga lokal hanya tinggal jalan kaki tidak lebih dari 5 menit untuk mencapai site. Menyediakan tempat publik skala kecil yang dibutuhkan oleh warga lokal seperti food hall, gym, ruang studi, lapangan panahan, eventspace, lounge, dll. Kehidupan publik yang sebelumnya dicuri oleh mall dan tempat lain dilokalisasikan, menciptakan sebuah sense of place, dan sense of community.
\end{abstract}

Kata kunci: kehidupan publik lokal; perumahan; third place

\begin{abstract}
Modern people have a demanding and busy life. Jakarta is not an exception. Whose people is growing rapidly in terms of socio economic standing into middle class. This class requires different types and patterns of usage of space. They prefer to live in suburubia, spends time in malls instead of local places, and usually have 9-5 jobs. The mall's role as a public space is problematic as it can siphon away public life that could've happen in local place which can shape a strong sense of place and character. Other than that, malls also requires a significant energy commitment to get to it, doesn't create community around it, exclusive to lower class people, etc. A local third place is proposed as a solution. To pull back public life into the suburbia. Something smaller in scale, making the visitors into people not mere consumer. A personal place, A place that forms communities, a palce that is local so people don't have to spend a lot of energy going to the place. A place that is open to all. A Third place. In this final project, the chosen site is right in the middle of a housing complex in Pulomas. Local residents would only have to walk no more than 5 minutes to visit the place. It provides public spaces that are in demand by local residents, such as food hall, gym, study space, archery hall, eventspace, etc in smaller scale. Public life that is stolen from the mall is taken back into the local place, creating a sense of place and community.
\end{abstract}

\section{Keywords: local public life; suburbia; third place}




\section{PENDAHULUAN}

Indonesia adalah negara berkembang yang kelas menengahnya terus bertumbuh pesat. Hampir 60 juta rakyat kelas menengah dan 120 juta calon kelas menengah di tahun 2018. Tahun 2020 jumlah rakyat kelas tengah diperkirakan akan mencapai 80 juta orang. Angka itu adalah angka terbesar di Asia Tenggara. Kelas menengah ini akan menjadi faktor signifikan dan menjadi penggerak ekonomi Indonesia. Kelas ini akan memiliki gaya hidup yang berbeda dari kelas menengah kebawah yang mempengaruhi kebutuhan ruang yang berbeda.

Kalangan ini umumnya memiliki pekerjaan formal, dan tingkat pendapatan yang lebih. Umumnya pekerjaan ini juga berlokasi jauh di luar kawasan perumahan, yang mengharuskan commute. Kemampuan ekonomi yang lebih baik memicu keinginan untuk mencari tempat tinggal yang lebih privat. Maka itu kelas menengah memilih untuk tinggal di perumahan dibanding kampung kota. Kebutuhan privasi ini juga meniadakan ruang publik sebagai third place yang biasanya tersedia di dekat tempat tinggal. Sebagai substitusi, mall dijadikan tempat publik.

Menurut Ray Oldenburg, mall adalah imitasi buruk dari third place. Mereka tidak membangun komunitas, pencapaian yang harus menggunakan mobil (dan mengkontribusi kepada kemacetan), dorongan untuk menghabiskan banyak uang (konsumerisme), rasa segan berasosiasi dengan orang yang tak dikenal, keseganan bagi kelas sosial yang lebih rendah, dll. Mall tidak membangun social capital. Kelas menengah butuh tempat yang lokal, yang bisa membangun komunitas dan menjadi tempat bagi semua.

Masalah utama yang dihadapi kawasan perumahan modern tidak adanya persepsi aktivitas yang bisa dilakukan di kawasan lokal menciptakan suasana perumahan yang sepi. Suasana ini menyebabkan penduduk lokal semakin enggan beraktivitas di kawasan lokal, yang menjadikan kawasan semakin sepi, dst. Hal ini menyebabkan rendahnya social capital dan sense of community di kawasan lokal, dimana warganya bahkan tidak mengenal tetangganya. Mengharuskan penggunaan satpam untuk keamanan. Dan tidak ada rasa komunitas yang dibutuhkan oleh manusia.

Perumahan formal kehilangan aspek penting yang hadir di kampung kota yang organik. Misal, gang yang umumnya ada di kampung. Gang ini adalah contoh dimana third place tumbuh subur di Indonesia. Aktivitas publik terlihat di jalan, anak-anak berlarian bermain bola, bapak-bapak duduk santai mengobrol di warung kopi, Ibu-ibu berbelanja di tukang sayur keliling,dll. Disini penduduk lokal saling mengenal sesamanya. Melalui kontak sosial, mereka mengetahui masalah, harapan, dan mimpi yang dimiliki sesamanya. Mereka menyadari bahwa mereka sama-sama memiliki kesamaan yang mendasar dari kemanusiaan sendiri. Sense of community lahir dari kesamaan itu dan menciptakan sense of place.

Namun bagi penduduk menengah ke atas yang membutuhkan privasi, model ini tidak bisa ditiru di dalam perumahan formal. Tidak semua positif dari ruang gang kampung ini. Seringkali ruang publik yang tercipta di gang kampung adalah hasil dari keharusan yang lahir dari kekurangan. Bagi mereka, social capital sangat penting untuk memenuhi kebutuhan hidup. Misal, masyarakat pedesaan tidak menggunakan jasa katering, sewa tenda, dll berbayar untuk menyelenggarakan acara nikahan karena kurangnya dana. Mereka bergantung kepada penduduk sekitar bergotong royong mengurus semua kebutuhan. Namun, bantuan ini tidak datang dengan percuma. Penduduk sekitar hanya rela membantu dengan syarat yang dibantu aktif dalam mengkontribusi dalam kegiatan kolektif seperti ini sebelumnya. Maka dari itu, ada ekspektasi berkehidupan sosial yang kuat di desa..Privasi juga tidak terjaga. Penduduk hampir tidak memiliki opsi untuk tidak melewati ruang publik ini.

Namun, tidak ada tempat berkumpul di perumahan menciptakan budaya yang individualis. Kurangnya tempat yang memberikan makna simbolis bagi suatu perumahan formal menjadikan warga lokal yang segan untuk berkunjung di tempat lokal. Akibatnya tidak ada budaya third place yang lokal. Social capital tidak terbentuk antar sesama. Dan dari situ tercipta dua karakter kelas yang berbeda. Kelas menengah kebawah dengan kehidupan kolektif yang kental, dan kelas menengah keatas dengan individualisme yang kental. 
Ruang publik yang dibutuhkan perumahan modern adalah ruang publik yang opsional, sentral, berskala publik, tidak menganggu privasi, namun ketika penduduk ingin see and be seen, tempat itu dengan mudah mengakomodasi kebutuhan ini.

\section{KAJIAN LITERATUR}

\section{Third place}

Menurut Ray Oldenburg di dalam bukunya The great good place, Third place adalah a place to be di luar tempat bekerja (second place) dan tempat tinggal (first place). Karakteristik third place adalah

- Inklusif terhadap semua jenis kelamin, usia, dan status sosial/ekonomi,

- Terjangkau secara ekonomi,

- Mudah dijangkau,

- Selalu tersedia,

- Sederhana,

- Penyetara sosial,

- Netral,

- Suasana yang ceria,

- Pembicaraan adalah kegiatan utama,

- A place to be.

Third place harus aksesibel. Harus mudah dijangkau dalam jarak berjalan kaki. Harus bisa diakses oleh semua kelas sosial. Pengunjung yang datang ke tempat ini menjadi setara dalam status sosial. Third place harus selalu sedia dalam mengakomodasi waktu kegiatan. Karena kepentingan rumah dan pekerjaan menjadi prioritas. Third place adalah tempat yang sederhana. Tempat itu juga menjadi tempat yang netral. Artinya tempat itu bukanlah ruang pribadi seseorang, yang mengharuskan kewajiban sosial yang berbeda dalam bertamu. Suasana third place adalah suasana yang ceria, dan pembicaraan adalah kegiatan utamanya.

Menurut Oldenburg, contoh third place yang ada di dunia adalah

- American Tavern

- Venetian Coffeehouse

- French Bistro

- German Beergarden

Contoh third place yang tumbuh di budaya Indonesia adalah

- Warung-warung kecil,

- Pedagang kaki lima

Third place adalah aspek yang penting di dalam kehidupan publik kota. Third place adalah pusat kehidupan publik informal. Dimana penduduk lokal bisa mengenal sesamanya, membangun koneksi sosial, melepas kejenuhan dari rutinitas, hiburan yang mudah dan murah, terbuka tanpa mengenal kelas, wajah publik sebuah komunitas dan menjadi pemersatu komunitas. Third place menumbuhkan rasa kepemilikan pada suatu tempat dan dari situ lahir sebuah a sense of place. Third place juga adalah tempat dimana social capital dibangun.

\section{Social capital}

"Social capital is the network of relationships among people within a society and the bridging of diverse people to function effectively" (Claridge, 2004). Social capital adalah jaringan sosial yang mempunyai nilai dan norma yang sama yang berguna untuk memfasilitasi kooperasi antar anggotanya. Contoh keuntungan dari social capital adalah akses terhadap sumber daya kolektif tanpa harus menggunakan jasa berbayar. Misal, kemampuan untuk meminjam alat seperti pemotong rumput dari tetangga tanpa segan menandakan social capital yang sehat. Dan kesempatan-kesempatan yang hanya bisa terjadi lewat koneksi sosial, misal lowongan pekerjaan yang diketahui dan ditawarkan lewat kenalan. Karena biasanya, manusia akan mencari sumber daya dari kenalannya dahulu. Misal jika seseorang 
membutuhkan jasa arsitek, biasanya dia akan menanyakan grup sosialnya dahulu, apakah mereka kenal seorang arsitek.

Juga rasa identitas bersama yang dibangun. Kontak sosial menciptakan pengertian akan sesama, dan dari situ tumbuh rasa kebersamaan yang menjadi identitas kolektif. Di masa modern ini, kebutuhan akan identitas kolektif menarik orang ke grup religius dan/atau etnis. $\mathrm{Hal}$ ini menyebabkan isolasi antara grup sosial dan menimbulkan perpecahan. Bagi Indonesia yang adalah negara plural, hal ini berbahaya. Masalah yang terjadi menyangkut social capital di Jakarta adalah miskinnya social capital lokal di lingkungan perumahan formal. Masyarakat modern enggan berinteraksi dengan sesamanya. Kondisi ini menyebabkan social capital yang sulit dibangun. Yang hasilnya adalah masyarakat yang individualis.

\section{Suburbanisasi dan kampung kota}

Suburbanisasi adalah proses terbentuk permukiman baru dan kawasan industri di pinggir wilayah perkotaan. Di Jakarta, pola perkembangan kota yang terjadi bisa dibagi menjadi 2, yaitu perkembangan formal dan informal. Perkembangan formal berupa gated communities, dan apartemen. Kedua tempat ini biasanya ditangani oleh perusahaan developer dan terencana. Sementara informal berupa kampung kota yang muncul secara spontan tanpa ada perencana sentral.

Di perumahan formal, biasanya mempunyai pembagian lahan yang rapih dan jelas, jalan depan yang lebar dan bersih, perumahan yang berupa detached atau semi detached, tidak adanya fungsi komersil biasanya menjadi karakter tempat ini. Biasanya penghuni tempat ini adalah masyarakat kelas menengah. Sementara di kampung kota, jalan depan biasanya sempit dan kotor, pembagian lahan yang kurang rapih dan jelas, bentuk perumahan yang padat, dan banyaknya fungsi komersil di level jalan menjadi karakter tempat ini.

\section{Suburbs vs Third places}

Studi ini mempelajari ruang publik informal apa yang diinginkan oleh penduduk suburban. Menurut studi ini, penduduk suburban ketika mereka beraktivitas di luar rumah, mereka lebih memilih untuk tidak bersosialisasi. Tapi lebih memilih kegiatan seperti olahraga dan kegiatan yang berhubungan dengan taman. Hal ini mengkonfirmasi bahwa penghuni perumahan menghargai privasinya lebih daripada masyarakat di kampung kota.

Namun, menurut studi ini, tempat publik informal masih diinginkan dalam seting perumahan rendah formal. Menurut responden studi ini, tempat di lingkungan mereka yang paling dibutuhkan adalah "a mini-park/large square with a range of recreation options (50\%). a place for teenagers (50\%). publicly accessible sports and recreation areas (e.g. sports fields. tennis courts. skate parks. outdoor gyms $-47.6 \%$.) adventure playground for children (42.9\%). cycling lanes with rest areas (40.5\%). local cafés. pubs. restaurants (40.5\%). a square in the vicinity of service and retail establishments (38.1\%). Besides. a few residents indicate the need for an open neighbours' spaces (e.g. village lounge. neighbours' community centre). Individual respondents mentioned a playground for small children. a broader offer of community-building events and activities at the Izabelin Cultural Centre. places for open meetings. and a shopping gallery." Maka dari itu, studi ini bisa menjadi sumber referensi dalam menyusun program.

"In addition, the residents of the studied suburban areas more frequently engage in activities that do not require establishing interactions with other people. They place more emphasis on physical activity or contact with nature rather than socializing with other residents.". Maka dari studi ini bisa didapat bahwa masyarakat perumahan formal membutuhkan tempat fasilitas olahraga, dengan fitur seperti alun-alun, dimana didukung oleh pertokoan kecil.

\section{METODE}

Metode yang digunakan dalam mendapatkan data mengenai lokasi dan fenomena berhubungan dengan tema adalah dengan cara 
- Observasi

- Wawancara

- Studi literatur

Observasi dilakukan dengan kunjungan langsung ke lapangan. Survey dilakukan dalam waktu 3 hari, pada hari senin, rabu dan jumat tanggal 19,21,dan 23 Agustus 2019. Tujuan pemilihan waktu ini adalah supaya terlihat karakter tempat secara panjang. Dan kegiatan apa yang terjadi rutin setiap minggu.

Data wawancara dikumpulkan juga untuk mengetahui lebih dalam mengenai problema yang terjadi di kawasan yang dipilih. Subjek dari wawancara ini adalah

- Ketua RT

- Pedagang sekitar

- Pengunjung sekitar

- Pelajar

- Hansip

Ketua RT, informasi mengenai kegiatan warga bisa didapat dari sumber otoritas ini. Pedagang sekitar juga selalu mengawasi kejadian yang terjadi. Pengunjung sekitar menjadi sumber perspektif utama mengenai problema yang terjadi di kawasan yang dipilih. Pelajar adalah salah satu pengguna sebuah kawasan yang mempunyai status sama dengan warga sekitar. Hansip memiliki informasi yang mendalam terhadap suatu tempat.

Faktor-faktor yang ditelusuri dari data wawancara itu adalah

- Kondisi social capital kawasan

- Karakteristik fisik tempat

- Kehadiran third place

- Waktu aktif

- Kebutuhan kawasan

Metode perancangan yang digunakan adalah dengan proses mimicry terhadap karakter lokal dan faktor yang dominan dalam site, yaitu vegetasi yang amat rindang.

\section{DISKUSI DAN HASIL}

\section{Analisis Makro dan Meso}

Kawasan yang dipilih adalah kawasan pulogadung, daerah pulomas.. Jakarta timur adalah kawasan dengan populasi terbanyak $(2,687,027$ di tahun 2010$)$ dibanding kota administrasi lain. Pusat Pemerintahannya berada di Cakung. Di sebelah utara, ia berbatasan dengan kota administrasi Jakarta Utara dan Jakarta Pusat. Sedangkan di sebelah timur, ia berbatasan dengan Bekasi. Kota ini, di bagian selatan, berbatasan dengan Kota Depok. Dan di sebelah barat, ia berbatasan dengan kota administrasi Jakarta Selatan. Jakarta timur dikenal sebagai kawasan permukiman dan komersil.

Pencapaian menuju tapak dapat menggunakan mobil dan kendaraan umum. Kendaraan pribadi dapat mencapai site dari jalan arteri perintis kemerdekaan dan ahmad yani. Dengan waktu pencapaian 5-7 menit menuju gerbang tol cempaka putih. Sementara jika menggunakan transportasi umum, dapat menggunakan busway dan angkot. Turun dari stasiun busway asmi dan cempaka tengah. Dari situ dapat menggunakan angkot 69 dan jak33 yang melewati depan kompleks. Dan dari situ berjalan kaki tidak lebih dari 5 menit menuju tapak. 


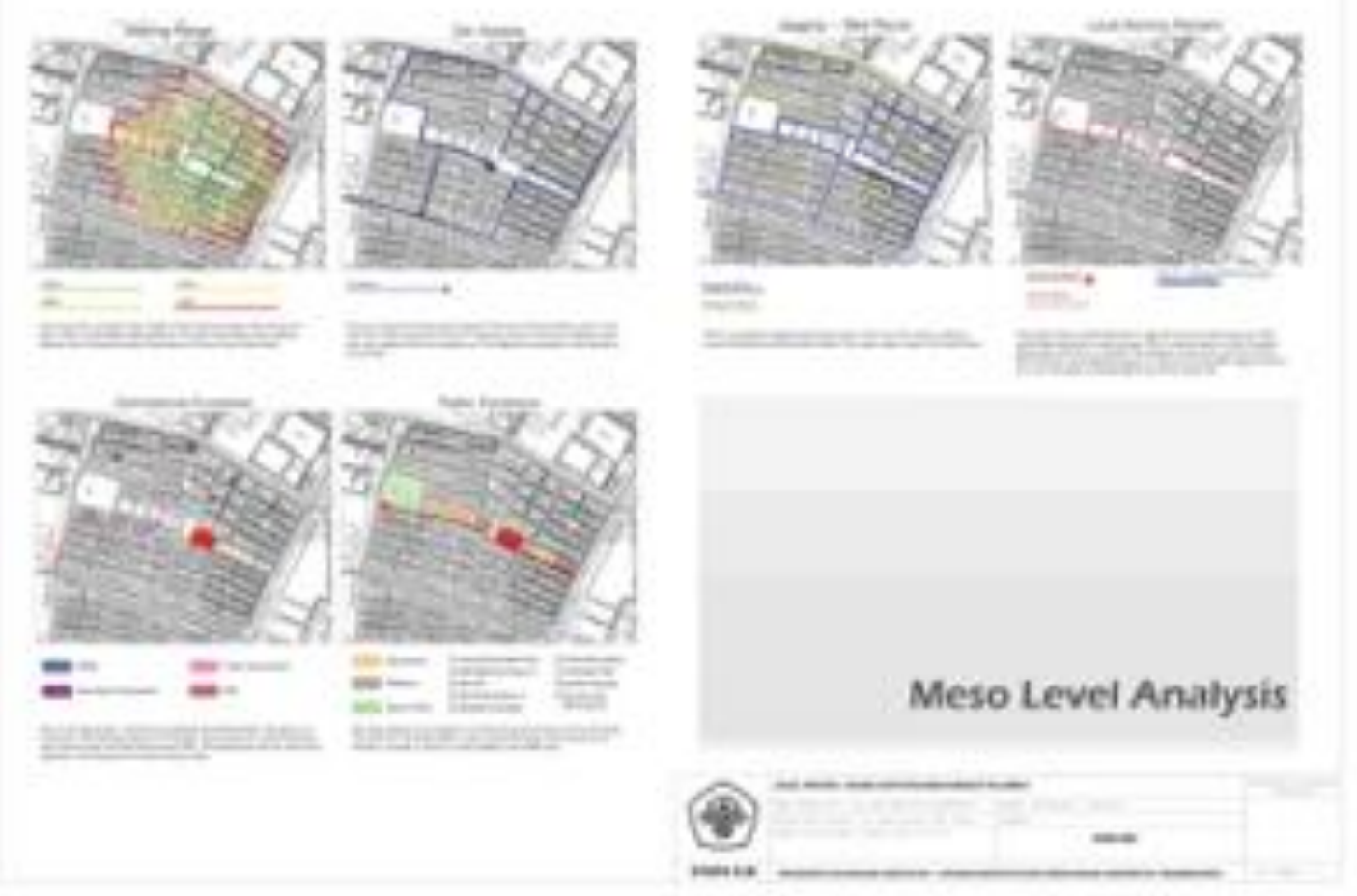

Gambar 1. Analisa Meso

Sumber: Penulis, 2019

Tempat yang signifikan dalam skala meso adalah pusat perbelanjaan Kelapa Gading, ITC, Velodrome, Jakarta Internasional Equestrian Park Pulomas (JIEPP) atau Pacuan kuda pulomas, dan Universitas ASMI. Kelapa gading adalah faktor yang dominan dalam kawasan ini. Kelapa gading menjadi pusat perbelanjaan penduduk sekitar yang selalu ramai. Pulomas adalah salah satu kawasan perumahan formal berkepadatan rendah. Kawasan ini adalah tempat yang sudah berdiri sejak 1970, memiliki waktu untuk menumbuhkan adaptasi terhadap permintaan kebutuhan fungsi komersil yang lokal. Maka itu kehidupan publik informal menjadi sebuah kemungkinan disini.

Susunan ruang yang terjadi di kawasan perumahan pulomas mengikuti suatu axis di tengah perumahan. Axis ini berorientasi barat ke timur. Di axis ini, adalah fungsi-fungsi publik seperti rumah sakit, sekolah, lapangan olahraga, dan tempat ibadah. Selain itu juga axis ini adalah ruang publik yang jelas, sehingga umumnya jalur jogging penduduk lokal dan anak-anak yang bermain sepeda melewati axis ini. Terdapat pengalaman ruang yang berbeda ketika memasuki aksis ini. Biasanya di ruang ini selalu terlihat aktivitas. Anak-anak bermain, siswa sekolah makan, Orang tua berolahraga, dll. Namun tidak semua penduduk lokal menggunakan ruang publik ini secara rutin. Alasan mereka adalah mereka tidak tertarik terhadap kegiatan yang bisa dilakukan di ruang publik ini. Dan umumnya, tempat mereka bisa bersantai (see and be seen) hanyalah berupa lapangan dan warung-warung.

Sesuai dengan karakteristik yang ada pada kawasan yang kurang padat seperti ini, biasanya tidak ada zonasi komersil. Namun terlihat tumbuh fungsi komersil rumahan yang menjadi indikasi permintaan akan fungsi komersil lokal di tempat ini. Namun fungsi komersil ini tersebar secara tidak teratur dengan beberapa titik padat. Jenis fungsi komersil yang terjadi sangat luas. Tukang jahit, bisnis kostum, toserba, dll. Namun menurut data interview, tempat komersil ini tidak pernah diketahui oleh penduduk. Penduduk menyatakan bahwa tidak ada visibilitas yang cukup terhadap bisnis rumahan itu, sehingga mereka tidak pernah menganggap bahwa ada bisnis di lokasi itu.

Hal ini tidak terjadi pada lokasi-lokasi dengan visibilitas tinggi seperti di depan sekolah Don Bosco dan At-taubah. Dimana visibilitas tinggi, bisnis itu menjadi ruang publik. Namun ada 
masalah lain yang terjadi di titik panas ini. Tidak semua warga merasa nyaman untuk menghabiskan waktu disana. Hal ini disebabkan oleh beberapa faktor. Salah satunya adalah kurangnya ruang personal yang menyebabkan ketidaknyamanan. Warga Pulomas menghargai privasi terhadap kewajiban interaksi sosial. Selain itu, masalah lain seperti kurangnya aktivitas yang menarik dan kurangnya kualitas perabot dan arsitektur di tempat-tempat itu menjadi alasan.

Pola penggunaan ruang publik yang terjadi ini juga menunjukan bahwa ada tempat-tempat khusus untuk grup grup tertentu. Misal di depan sekolah don-bosco, yang biasanya makan di sana adalah murid-murid Don-bosco. Sama juga seperti di At-Taubah. Selain itu, tempat hangout selain di depan sekolah juga memiliki teritorialitas dimana satu tempat makan adalah tempat murid don-bosco dan tidak dikunjungi oleh murid At-taubah.

Penduduk lokal tidak memiliki persepsi bahwa ruang publik yang terjadi di pulomas sebagai destinasi yang layak. Ini disebabkan oleh persebaran ruang publik yang tersebar, dan ruang personal yang tidak mencukupi, serta kurangnya kualitas arsitektur tempat publik itu. Di dalam kompleks perumahan pulomas, jarak tempuh berjalan kaki dari ujung kompleks ke site maksimal mencapai 400-500 meter. Dimana jarak nyaman berjalan kaki adalah sekitar 400 meter. $85 \%$ penduduk lokal berada dalam jarak nyaman berjalan kaki. Karena sifat third place yang lokal, maka diperkirakan pengunjung bersifat lokal, dan karena jarak dekat, tidak memerlukan kendaraan bermotor, sehingga parkir yang disediakan tidak begitu banyak.

Penduduk di perumahan pulomas mayoritas memiliki pekerjaan 9-5. Penduduk pulomas memiliki status sosial ekonomi sebagai kelas menengah, jika dilihat dari piramida penduduknya.

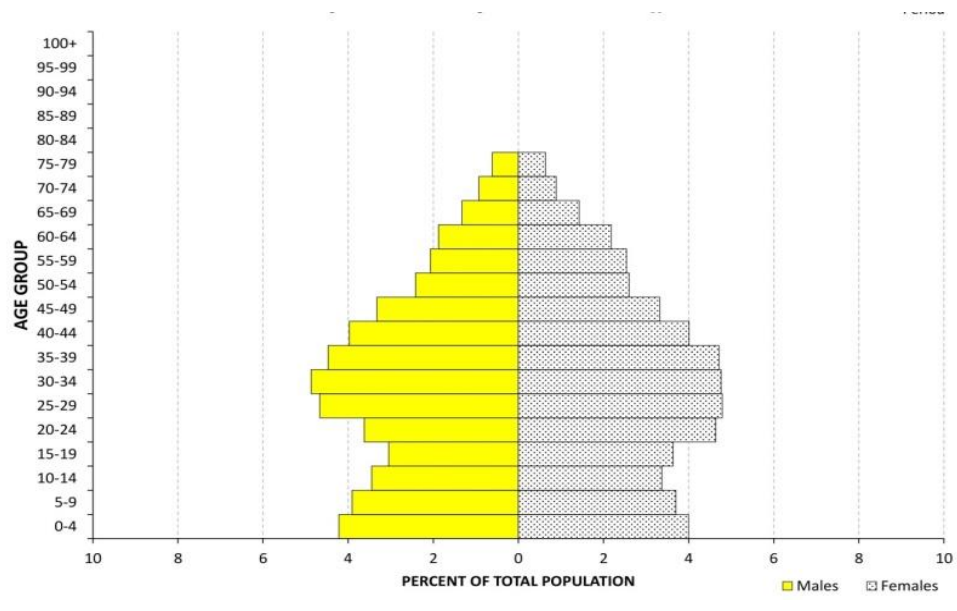

Gambar 2. Piramida penduduk kayu putih Sumber: BPS, Jakarta Timur

Dari data kependudukan, bisa dilihat bahwa karakter penduduk kawasan pulogadung adalah 35-50 tahun dengan gembungan umur balita yang signifikan. Ini mengindikasikan sebuah demografi yang mapan, yang sudah memiliki keamanan finansial, memiliki disposable income, dan pola perilaku yang lebih fokus kepada keluarga. Maka itu, dibutuhkan tempat bagi keluarga dan orang tua. Tanpa mengabaikan kebutuhan demografi lain yang signifikan Maka dari semua itu, secara garis besar masalah dari kawasan ini adalah

- Social capital yang rendah,

- tidak adanya interaksi antara fungsi publik menciptakan gelembung-gelembung yang individualis,

- Tidak adanya destinasi lokal yang membentuk preferensi penduduk sekitar untuk pergi ke mall,

- Kurangnya visibilitas untuk bisnis lokal

- Tidak adanya wadah lokal untuk mengadakan acara kolektif, dan 
Kekuatan dari kawasan ini adalah

- Potensi kehidupan informal yang kuat, namun terpisah

- Komunitas yang konstan dan aktif yang berupa komunitas religius

- Demografi yang mapan

\section{Analisis Mikro}

Site yang dipilih memiliki luas $4500 \mathrm{~m} 2$. Berbatasan barat dengan lapangan at-taubah, timur dengan rumah sakit omni pulomas, utara dan barat berbatasan dengan perumahan. Site ini mempunyai lokasi di axis ruang publik pulomas.

Tapak terpilih berada pada zonasi k1 yaitu zonasi perdagangan, perkantoran dan jasa. Untuk zonasi kawasan $\mathrm{k} 1$ sub blok 036 pada kawasan kayu putih, intensitas penggunaan yang berlaku adalah
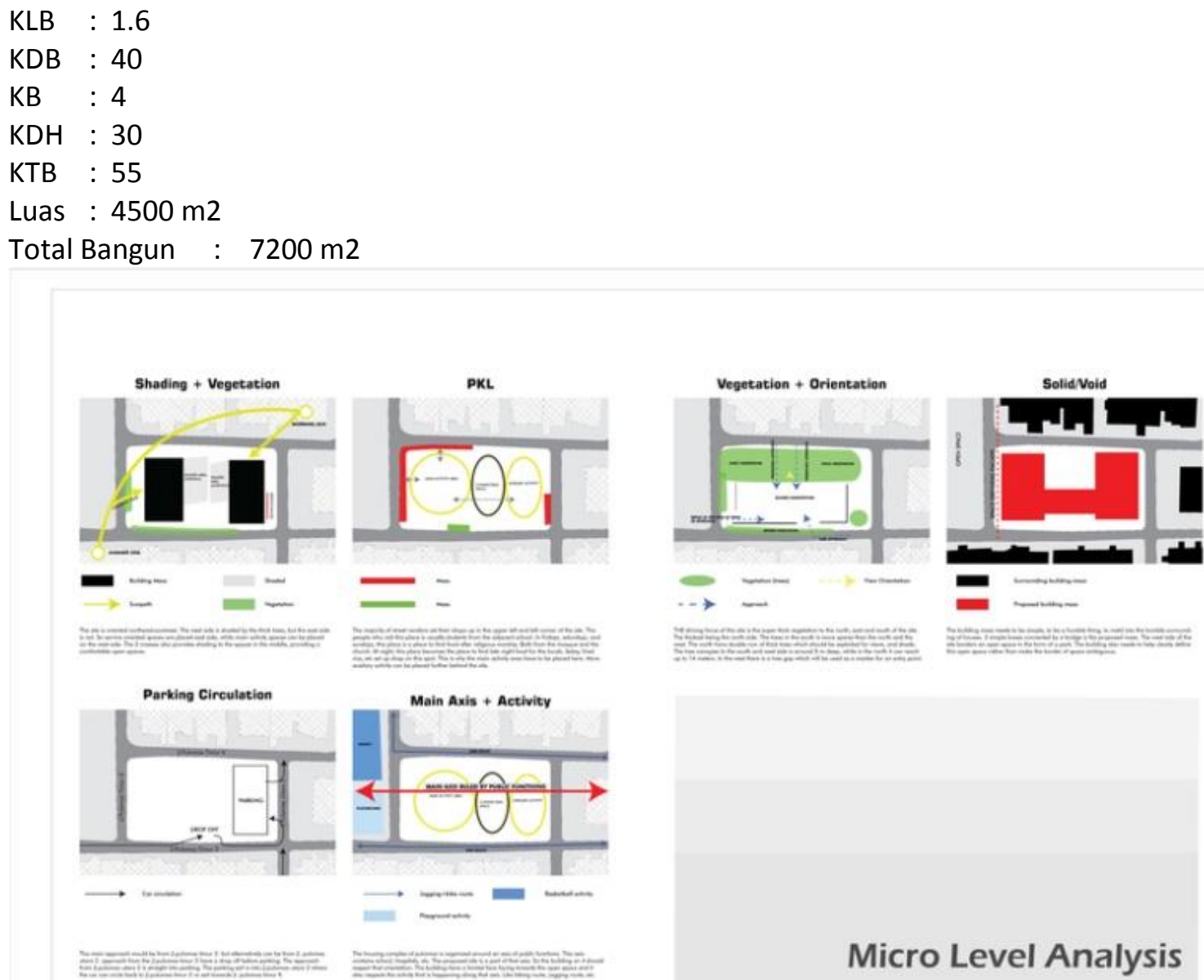

Micro Level Analysis
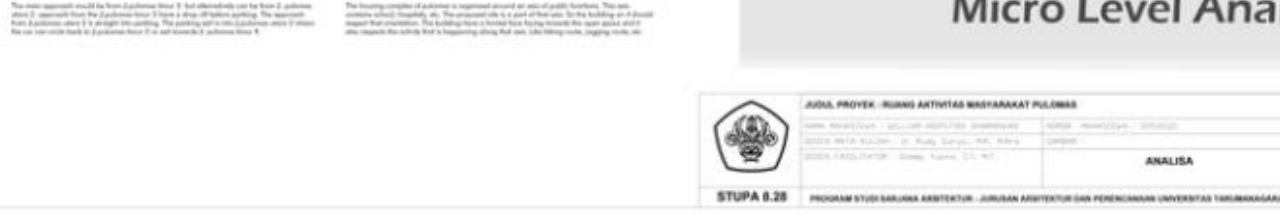

Gambar 3. Analisa Mikro

Sumber: Penulis, 2019

Faktor paling dominan dari tapak ini adalah pepohonan yang rimbun di mengelilingi tapak. Di bagian utara tapak, adalah bagian yang paling rindang. Di bagian ini, adalah dua baris pohon rindang. Lebar kanopi pohon itu bisa mencapai 10 meter. Kanopi ini menjorok ke dalam tapak. Sementara di bagian barat dan selatan tidak selebat bagian utara hanya dengan satu baris pohon saja dengan lebar kanopi 8 meter. Sementara di bagian timur tidak ada pohon sama sekali. Karena vegetasi yang rimbun, sinar panas matahari sore bisa di halangi oleh kanopi 
pohon sehingga menaungi bagian dalam tapak, mengurangi klimat mikro menjadi lebih nyaman.

Di bawah kanopi pohon ini juga digunakan sebagai ruang publik oleh masyarakat sekitar. Karena naungannya dari panas matahari menciptakan klimat mikro yang nyaman untuk kegiatan. Di bagian barat yang berhadapan langsung dengan lapangan basket adalah berbagai warung makanan yang melayani pengunjung lapangan basket dan sekolah at-taubah. Di bagian utara digunakan oleh beberapa warung dimana biasanya umat gereja dan masjid mencari makan. Pada malam hari, di bagian barat ramai akan pedagang sate, nasi goreng, dll. Sementara ada satu pedagang sate di bagian timur.

\section{Program Ruang}

Program yang diusulkan adalah program yang mengakomodir kegiatan sehari-hari warga sekitar. Hal ini dipilih ketimbang dengan program yang bersifat lebih novel karena sifat third palce yang sederhana dan keseharian. Program ruang yang diusulkan adalah

- Foodhall

- Gym

- Ruang studi

- Ruang komersil

- Ruang event

- Plaza

- Ruang panahan

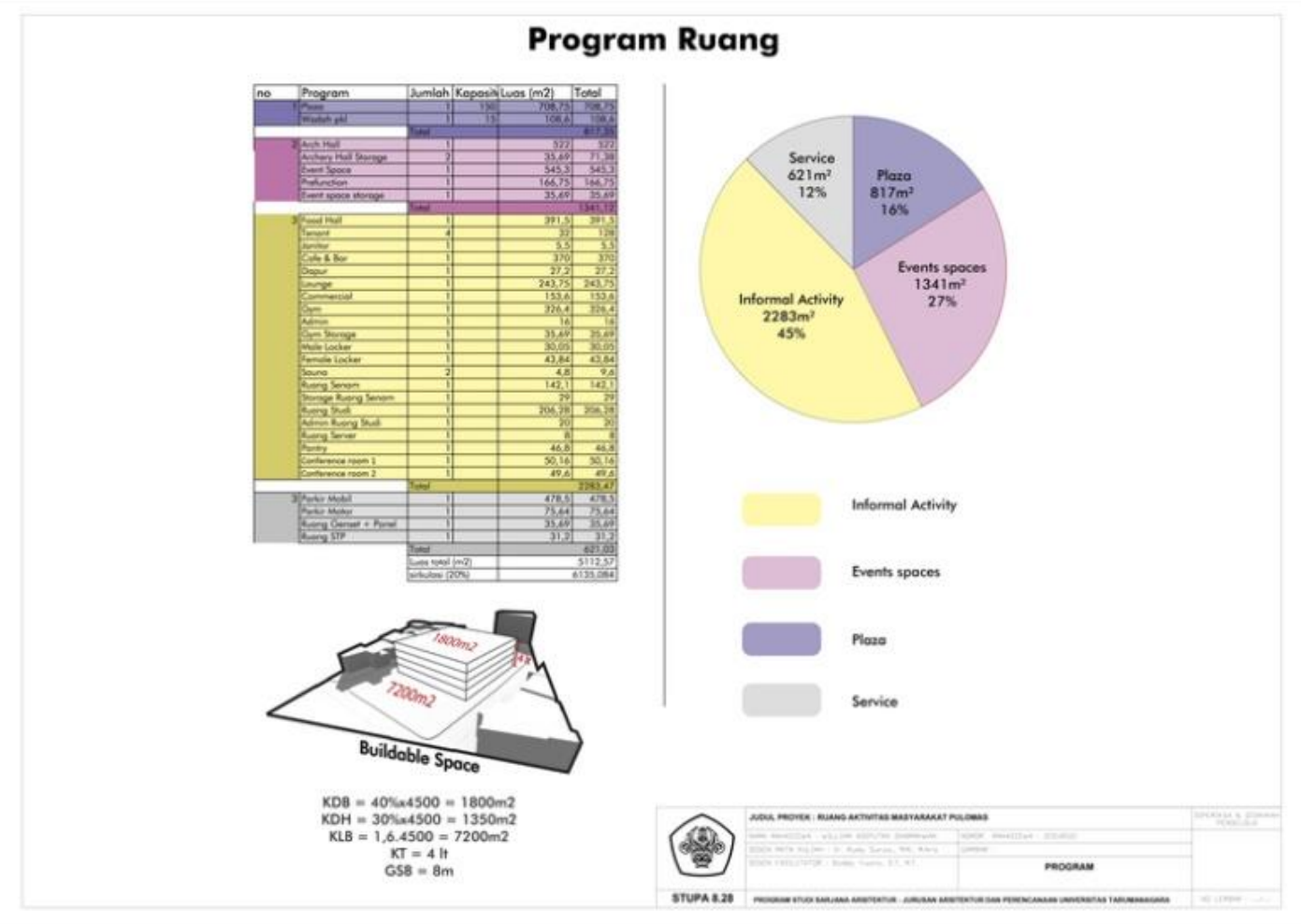

Gambar 4. Program Ruang

Sumber: Penulis, 2019

Foodhall dipilih sebagai program pokok. Makanan digunakan sebagai pengikat universal tidak peduli terhadap minat individu yang berbeda-beda. Selain untuk tempat makan, program ini juga menjadi ruang utama yang bisa digunakan lebih dari sekedar makan saja. Susunan ruang yang mengikuti konsep foodcourt membebaskan pengunjung menggunakan ruang untuk bersosialisasi, bekerja, bertemu dengan klien, dll. 
Gym adalah program lain yang dipilih. Gym adalah kegiatan yang sifatnya reguler. Dan mempunyai nilai strategis jika letaknya berada dekat dengan penduduk sekitar. Karena tidak perlu lagi mengeluarkan energi yang berlebih untuk pergi ke gym di mall yang jauh. Karena mereka bertemu dengan warga lokal, maka diharapkan membangun social capital sambil memenuhi kebutuhan seharian. Siswa di kawasan pulomas tidak memiliki tempat yang layak dimana mereka bisa belajar di luar suasana kelas. Belajar bersama teman di suasana yang lebih informal bisa menjadi lebih efektif dari belajar di kelas. Namun karena kurangnya tempat yang layak, mereka menggunakan mall sebagai tempat belajar itu.

Ruang event dapat digunakan sebagai tempat mengadakan acara spesial. Misal konser kecil-kecilan, pertemuan warga, presentasi lokal, upacara kelulusan, dll. Sementara plaza dapat digunakan sebagai ruang acara spesial yang bersifat lebih ke luar ruangan. Seperti acara upacara yang sering dilakukan di perumahan namun tidak memiliki tempat yang layak. Ruang panahan menampung klub panahan yang ada di pulomas. Klub ini biasa menggunakan tempat yang tidak layak sebagai lapangan panahan. Yaitu di lapangan parkir bmx track. Klub panahan aktif pada hari jumat sabtu dan minggu. Di hari lain, ruang ini bisa digunakan sebagai ruang publik indoor yang informal.

\section{Sintesis Desain}

Kehidupan publik yang sebelumnya dicuri oleh mall dan tempat lain dilokalisasikan, menciptakan sebuah sense of place, dan sense of community. Siswa DonBosco dan At Taubah seringkali memilih mall untuk menjadi tempat belajarnya, bisa menjadikan tempat ini sebagai basecampnya. Kegiatan senam yang sering diadakan di rumah ibu-ibu masing-masing bisa menunjukan kemampuannya disini. Klub panahan yang beraktivitas di tempat yang tidak layak(di tempat parkir) mempunyai tempat yang layak dan menjadi pusat perhatian dari kegiatan, Food hall dan plaza menjadi focal point yang jelas sebagai tempat to be see and be seen. Umat katolik dan islam yang mencari makan di tapak terpilih setelah ibadah. Lalu tidak perlu lagi menggunakan mobil jauh jauh untuk berolahraga di gym, hanya perlu berjalan kaki dan bisa saja dari sini bisa saling kenal teman sesama perumahan. Dalam bentuknya sendiri, faktor yang dominan dari tapak adalah axis fungsi publik yang linear, taman yang berada tepat disamping site membentuk muka, dan vegetasi yang sangat rimbun.
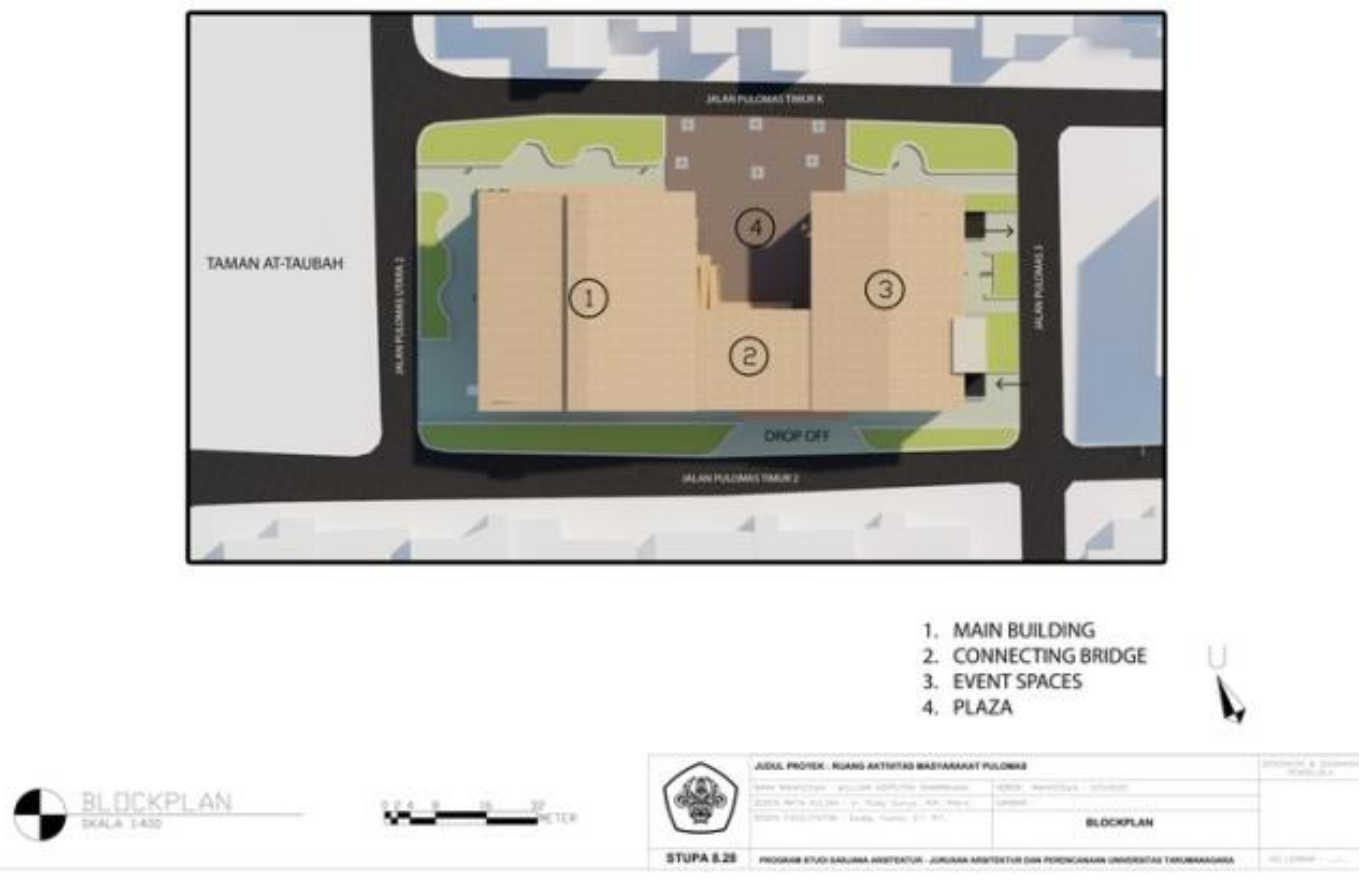

Gambar 5. Blokplan

Sumber: Penulis, 2019 
Bentuk yang dikembangkan adalah dua blok simple disusun dalam axis panjang tapak dan fungsi ruang publik. Massa terdiri dari massa depan dan belakang. Bagian depan adalah bagian yang menghadap lapangan basket, di arah barat. Kedua massa dikoneksikan oleh massa penghubung di antaranya. Massa depan digunakan untuk kegiatan yang lebih informal, dan keseharian, sementara massa belakang digunakan sebagai ruang event, dan lebih formal. Di tengah kedua massa ini adalah plaza yang bisa digunakan secara formal dan informal. Bentuk ini adalah bentuk yang sederhana, bentuk yang tidak bertabrakan dengan gaya sederhana di lingkungan.

Arsitektur ini mengajak pengunjungnya untuk mempunyai koneksi visual terhadap sesama, dunia luar, dan vegetasi yang dominan di sekeliling tapak. Permukaan lantai dasar di kedua massa diangkat setinggi 2 meter dari tanah, menciptakan ruang yang terpisah terhadap level jalan tanpa harus menggunakan tembok. Untuk ruang foodhall, pembatas antara ruang terbuka ini dan ruang luar menggunakan tanaman tembok yang hanya setinggi 1 meter. $\mathrm{Di}$ massa belakang ruang ini dibungkus oleh kaca dan elemen façade. Ruang terbuka ini memungkinkan pengunjung untuk mempunyai koneksi ruang yang sama terhadap pengunjung ya ng berada di ruang berbeda. Menciptakan kesamaan sambil menjaga privasi.

Massa belakang dan depan dibungkus dalam satu atap dengan struktur portal. Kulit ini mengikat ruang menjadi satu dan menciptakan kesatuan ruang, sekaligus bermanfaat untuk ventilasi, shading, estetis, dll. Façade struktur adalah panel engineered wood yang berpori sehingga memperbolehkan koneksi visual, supaya tidak tampias terkena hujan, sirkulasi udara, dan keindahan estetis. Kayu ini dilapisi oleh waterproofing sehingga kuat air.

Materialitas yang dipilih adalah CLT sebagai gesture mirroring elemen site yang dominan oleh pohon yang lebat. Pemasangan juga lebih rapih, cepat, tidak berisik, dan ramah lingkungan. Fitur yang penting mengingat konteks lingkungan yang adalah kompleks perumahan. Kayu juga adalah material yang secara estetis indah. Dan secara psikologis menenangkan pengunjung yang datang.



FOOB HACL
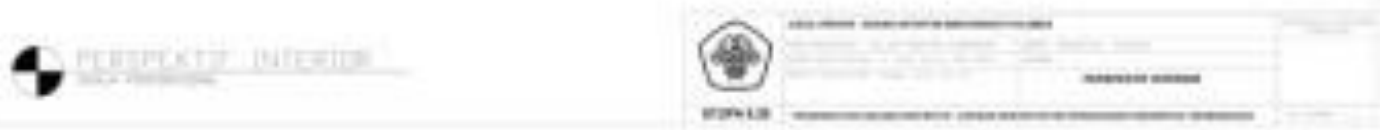

Gambar 6. Perspektif foodhall

Sumber: Penulis, 2019 
Untuk massa di depan, struktur portal menciptakan atrium vertikal yang mengikat ruangruang lainnya di lantai atas. Ruang ini menciptakan kesatuan terhadap pengguna ruang lainnnya di atas. Tepat di atas foodhall adalah kafe dan bar dimana pool dan permainan disediakan selain makanan. Tempat ini memiliki koneksi yang erat dengan foodhall di bawahnya. Kafe dan bar ini terbuka dan dapat melihat langsung kanopi pohon. Di ruang yang lebih tinggi ini, pengunjung mengalami pohon dari beberapa level, level dasar, kanopi dan atas kanopi. Dari lantai dasar, lantai 2, dan lantai 3.

\section{KESIMPULAN DAN SARAN}

Ruang publik masih dibutuhkan oleh tipologi kompleks perumahan. Mengingat cepatnya pertumbuhan ekonomi Indonesia, khususnya Jakarta yang menaikan drajat sosio ekonomi warganya. Sehingga membutuhkan ruang tempat tinggal yang berbeda juga. Dimana di tipologi kompleks perumahan terjadi kekurangan social capital dan sense of community yang berakar dari tidak adanya ruang publik yang layak di pikiran penduduk lokal. Maka dari itu, proyek ini adalah upaya untuk menyelesaikan masalah makro ini dalam konteks lokal yang mikro, yaitu di tapak terpilih di pulomas. Ruang ini adalah wadah bagi masyarakat lokal untuk melakukan aktivitas kesehariannya, yang bisa menjadi katalis pembentuk komunitas dan social capital. Untuk kedepannya, masalah lain yang harus dihadapi oleh tipologi kompleks perumahan ini adalah streetscape yang tidak menarik bagi pejalan kaki. Sehingga menjadikan tipologi kompleks perumahan yang baru. Yang adalah sebuah tempat yang lebih dari dimana penduduk tidur dan berada di rumah saja, namun benar-benar sebuah tempat dimana mereka sesungguhnya tinggal.

\section{REFERENSI}

Claridge, T. (2004) Social Capital Literature: Definitions of Social Capital. Available at: http://www. socialcapitalresearch.com/literature/definition.html Accessed on: 16/08/2019.

Kepkowicz, A. et al. (2019). IOP Conf. Ser.: Mater. Sci. Eng. 471092078

Neufert, E. (2012). Neufert Architects' Data, Fourth Edition. In E. Neufert, Neufert Architects' Data, Fourth Edition. Germany: Bauwelt-Verlag.4

Oldenburg, R. (1989). "The Great Good Place : Cafes, Coffee Shops, Bookstores, Bars, Hair Salons, and other Hangouts at the Center of a community."

Trancik, R. (1986). "Finding Lost Space : Theories of Urban Design".

https://ekbis.sindonews.com/read/1372651/33/kelas-menengah-mendekati-60-juta-akanjadi-penggerak-ekonomi-1548156120 diakses tanggal 1 agustus 2019

https://www.archdaily.com/490241/nine-bridges-country-club-shigeru-ban-architects diakses tanggal tanggal 1 agustus 2019

https://www.resilientcity.org/index.cfm?id=22432 diakses tanggal 1 agustus 2019

https://www.theatlantic.com/business/archive/2016/05/friendship-privilege-income/481884/ diakses tanggal 1 agustus 2019

https://www.tandfonline.com/doi/full/10.1080/17406315.2016.1190582 diakses tanggal 1 agustus 2019 